\title{
INNOVATIVE LASER TECHNOLOGIES IN BRAIN TUMORS SURGERY
}

\author{
V.D. Rozumenko \\ Prof., Dr. Sci. (Med.), Head of the clinic \\ Clinic of Intracerebral Tumors \\ SI "Romodanov Neurosurgery Institute of NAMS of Ukraine" \\ 32 Platona Mayborody St., Kyiv, 04050, Ukraine \\ tel/fax: +38 (044) 483-92-19 \\ e-mail: rozumenko.neuro@gmail.com \\ ORCID 0000-0002-8774-6942
}

The article presents the results of application of innovative laser technologies in the surgical treatment of brain tumors. The article reviews the problems of a differentiated approach to the choice of the laser source as well as optimization of intraoperative application of laser dissection effects, vaporization, coagulation and thermal destruction of tumor tissue, providing increase of surgery efficiency degree and patients' quality of life. The results of studies on the development of laser surgery planning method and intraoperative navigation maintenance for brain tumors laser surgery method are presented.

Key words: brain tumors, laser technologies, neuronavigation.

\section{ІННОВАЦІЙНІ ЛАЗЕРНІ ТЕХНОЛОГІї В ХІРУРГІї ПУХЛИН ГОЛОВНОГО МОЗКУ \\ В.Д. Розуменко}

ДУ«Інститут нейрохірургї ім. акад. А.П. Ромоданова НАМН Украӥни», м. Киӥв, Украӥна

У статті представлені результати застосування інноваційних лазерних технологій при хірургічному лікуванні пухлин головного мозку. У статті розглядаються проблеми диференційованого підходу до вибору лазерного випромінювача, а також оптимізація інтраопераційного застосування ефектів лазерного розтину, випаровування, коагуляції та термічного руйнування пухлинної тканини, що забезпечує підвищення ступеня ефективності хірургії та якості життя пацієнтів. Наведено результати досліджень щодо розробки методу планування лазерної хірургії та інтраопераційного навігаційного обслуговування методу лазерної хірургії пухлин головного мозку.

Ключові слова: пухлини мозку, лазерні технології, нейронавігація.

\section{ИННОВАЦИОННЫЕ ЛАЗЕРНЫЕ ТЕХНОЛОГИИ В ХИРУРГИИ ОПУХОЛЕЙ ГОЛОВНОГО МОЗГА}

\section{В.Д. Розуменко}

ГУ «Институт нейрохирургии им. акад. А.П. Ромоданова НАМН Украины», г. Киев, Украина

В статье представлены результаты применения инновационных лазерных технологий в хирургическом лечении опухолей головного мозга. В статье рассматриваются проблемы дифференцированного подхода к выбору лазерного излучателя, а также оптимизация интраоперационного применения эффектов лазерного рассечения, испарения, коагуляции и термической деструкции опухолевой ткани, что позволяет повысить эффективность операции и качество жизни пациентов. Представлены результаты исследований по разработке метода планирования лазерной хирургии и интраоперационного навигационного обслуживания метода лазерной хирургии опухолей головного мозга.

Ключевые слова: опухоли головного мозга, лазерные технологии, нейронавигация.

\section{Introduction}

The problem of brain tumors surgical treatment is one of the most pressing in modern oncology. The incidence rate of primary benign and malignant brain tumors in industrialized countries is more than 14 cases per 100 thousand people. Metastatic (secondary) brain tumors are being diagnosed in 3-4 times more frequently. The number of brain metastatic tumors increases significantly every year, due to the wide- spread growth of cancer pathology as a whole. [1] Annually, neurosurgical clinics of Ukraine carry out up to 5000 surgeries for brain tumors. The efficiency of therapeutic interventions in neoplastic brain lesion is defined by the level of applied range of advanced technical means of early highly informative diagnosis and innovative surgical techniques. Such modern methods of neuroimaging diagnostics, as X-ray computed tomography (CT), magnetic resonance imaging 
(MRI), positron emission tomography (PET), single photon emission computed tomography (SPECT), allow revealing the tumor brain lesion in the early disease stages, and thus define the appropriate range of therapeutic means of influence on tumor process, providing the treatment efficacy, quality of life and patients life expectancy increase. The key to successful surgical treatment of patients with brain tumors is application of modern microsurgical techniques of tumor removal, neuronavigation, ultrasound and endoscopic techniques. The brand new high level of brain tumors surgery is achieved by laser technologies application. [2-8]

\section{Materials and methods}

With the use of surgical laser technology, 660 surgeries for removal of intracerebral and extracerebral brain tumors have been conducted at the SI "Romodanov Neurosurgery Institute, National Academy of Medical Sciences of Ukraine". We have our own experience in clinical application of surgical laser devices of domestic and foreign production, and this allowed the development of innovative technologies for surgical treatment of brain tumors of various sites, histological structure and grade. To remove the brain tumors, we applied the following devices: "Sayany MT" carbon dioxide laser device (emission wavelength of $10.6 \mathrm{mi}-$ crometers), "Raduga-1" neodymium-YAG laser device (emission wavelength of 1.06 microns), COHERENT "Versa Pulse Select" holmium-YAG laser (emission wavelength of 2.1 micron), "Lika-khirurg" (wavelength 0.808 micron) and "Lika-khirurg M" (wavelength 1.47 microns) semiconductor laser devices.

Preoperative examination included performance of X-ray computed tomography, magnetic resonance imaging, functional magnetic resonance imaging, magnetic resonance angiography, magnetic resonance tractography, single photon emission computed tomography. Comprehensive assessment of the imaging studies findings allow the tumor process verification and obtaining of the diagnostic information about the topography, size, tumor growth areas characteristics, lesions of the surrounding anatomical structures and borderline functionally important and vital brain structures, to identify the main sources tumor blood supply, to determine the degree of tumor vascularization, to establish the presence of cystic component, necrotic changes sites, and foci of intra-tumor hemorrhage.

Currently, the clinic of neuro-oncology Institute of Neurosurgery performs laser brain tumors microsurgery with intraoperative application of "StealthStation TREON Rlus" neuronavigation station (Medtronic, USA), which is equipped with a telemonitoring system in real time mode, which allows for control and correction of all stages of laser-surgical effects on tumor. $[1,9]$ In application of surgical navigation, the results of neuroimaging studies were integrated into the navigation system and spatial modeling of 3D relief of cere- bral hemispheres surface, brain convolutions and sulci cerebri was performed, anatomical and topographical tumor relationship to the surrounding brain structures, main arteries, venous basin, brain ventricular system was determined, stereotactic calculations and tracing for the best transcortical surgical access to the tumor, tumor segmentation and contouring, as well as the choice of the laser irradiation area was performed, Subsequently, we determined the optimum extent of planned surgical intervention and differentiated use of laser technology, using the developed laser microsurgery techniques and methods of laser tumor removal.

\section{Results and discussion}

In laser-surgical brain tumors removal the following methods are used: method of tumor tissue laser incision and excision, method of laser photocoagulation with devascularization of hypervascularuzed tumor areas, method of layer-by-layer laser vaporization of small tumor parts in there expansion to the functionally important and vital brain areas, method of laser thermal destruction of invasive expanding tumor fragments. The destructive effect of the tumor tissue exposure to high-energy laser radiation is confirmed by morphological studies, including electron microscopy findings. [10-15] Modulating the laser parameters enables achievement of the intended effect of ablative influence on the tumor tissue, providing the surgery efficiency due to the cytoreduction. At that, it is necessary to apply the differentiated approach to laser radiation of different wavelength, of lasing regime, of radiation power and power density. To remove the tumor tissue using a laser vaporization method, the most appropriate way is to use the infrared carbon dioxide laser, the defocused beam of which allows performance of visually controlled layer-by-layer tumor tissue "evaporation", and this eliminates the factor of traction mechanical effect on adjacent brain structures. Infrared YAG-neodymium laser radiation has good coagulation properties, ensuring the effect of tumor tissue devascularization. Therefore, exposure of hypervascularized tumor areas to the radiation of YAG-Neodymium laser leads to coagulation of newly formed abnormal tumor vessels, resulting in their thrombosing, and then the tumor tissue becomes "bloodless", its size decreases (shrinks), and tumor cells "die" due to hyperthermia. Application of laser destruction method eliminates the need for tumor resection and surgical ablation of tumor tissue fragments directly in functionally important and vital brain areas, intraoperative traumatization of which is associated with the risk of postoperative persistent neurological deficit. YAG-holmium laser radiation allows performance of segmental excision and removal of calcified and ossified high-density tumor tissues. Currently, to remove the tumors of functionally significant speech-motor brain areas, as well as tumors that spread to the vital median brain formations, we use the "Lika-Khirurg" (214 surgeries performed) and 
"Lika-KhirurgM" (37 surgeries performed) semiconductor surgical laser devices; at high power density, their radiation provides tumor tissue dissection and vaporization, and when the density is lowered, the effect of laser photocoagulation and laser thermal destruction is achieved. For the removal of tumors, which spread to the "critical" functionally significant (mainly speech-motor areas) and vital (median) brain parts, the laser stage of surgery is performed under control of neuronavigation, which ensures a high degree of laser radiation accuracy in exposure of the tumor tissue within the tumor "node", without damaging the adjacent brain structures. The final stage of the surgery with application of the defocused laser irradiation includes performance of thermal destruction of tumor infiltration areas of the resected tumor bed walls.

We have developed an innovative method of brain tumors removal with laser, applied together with the multimodal neuronavigation in real time mode, and this allows exposure of the tumor tissue to the laser thermal effect. And imaging of this tissue on the screen is provided due to the computerized integration of MRI, MSCT and SPECT images into the navigation station. The virtual 3D planning of laser surgery is performed at the preoperative stage, when we determine the areas for laser irradiation and adjacent topography of the brain structures, main arterial vessels, and venous basins. $[9,16]$ Thus, using the neuronavigation based on the results of CT, MRI, functional MRI, MR-tractography, MR-venography and SPECT studies surgical access to the tumor and the laser radiation path are planned. In the process of laser-surgical tumor removal, the data of virtual 3D planning of the surgery are directly compared to the image of the surgical area in real time mode, and this allows not only to perform the navigation control of all surgery stages, but also to perform the intraoperative navigation verification of the removed tumor tissue extent.

\section{Conclusion}

Laser surgery of brain tumors is a progressive method of modern neurooncology. The brand new highly effective methods of brain tumors removal have been developed, using the laser technologies. Application of innovative laser-surgical methods of brain tumors removal, based on a differentiated use of high-energy laser radiation of different wavelengths and power density, allows reduction of the surgery risks and increasing the surgery efficiency degree, providing the high quality of life for patients, who underwent surgery. Together with multimodal neuronavigation, the method of laser thermal destruction of brain tumors, used in removing of tumors in functionally important and vital brain parts, enables intraoperative orientation in topographic relationship of tumor to the surrounding anatomical structures, and thus the accuracy of tumor tissue exposure to laser is improves and laser surgical procedures safety is provided. New opportunities of laser surgery in intracerebral malignant tumors are available due to the intraoperative application of fluorescent tumor imaging method with application of 5-aminolevulinic acid; this allows identification of tumor tissue expansion and performance of tumor laser irradiation and thermal destruction, preserving the anatomical and functional integrity of the adjacent brain structures. $[5,17]$ A promising method of laser radiation application in the deep intracerebral tumors is the development of endoscopic navigation controlled laser interstitial thermal therapy method. [11,16,18-20] A combined performance of thermal destruction and photodynamic therapy may be considered, as a highly efficient method of increasing the surgery efficiency in infiltrative intracerebral tumors. [21-24]

\section{References}

1. Rozumenko VD. Progressive technologies in surgery of brain tumors. Onkologiya [Oncology]. 2012;14(2):97-100. (in Russian)

2. Zozulya YuA, Romodanov SA, Rozumenko VD. Lazernaya neyrohirurgiya [Laser neurosurgery]. Kiev: Zdorovia Publ; 1982. 168 p. (in Russian)

3. Rozumenko VD. Laser surgery of brain tumors. Fotobiol. ta Fotomed. [Photobiol. and Photomed.]. 2010;7(3,4):16-22. (in Russian)

4. Ascher PW. Der CO2-laser in der Neurochirurgie. Munich: Molden; 1977.83 p.

5. Eyupoglu IY, Hore N, Savaskan NE, Grummich P, Roessier K, Buchfelder M, et al. Improving the extent of malignant glioma resection by dual intraoperative visualization approach. PLoS One. 2012;7(9):e44885.

6. Jain KK. Handbook of laser neurosurgery. Springfield: Charles C Thomas Publisher; 1983. 147 p.

7. Krishnamurthy S, Powers SK. Lasers in Neurosurgery. Lasers Surg Med. 1994;15(2):126-67.

8. Robertson JH. Carbon dioxide laser in neurosurgery. Neurosurgery. 1982;10:780.

9. Rozumenko VD. Neuronavigation technology of virtual 3D planning and intraoperative support of laser thermodestruction of intracerebral tumors of cerebral hemispheres. Ukr. neirokhirurh. zhurn. [Ukr. Neurosurg. J]. 2015;3:43-9. (in Russian)

10. Nosov AT, Rozumenko VD, Semenova VM, Medianyk IO. Morpho-functional changes of the brain under the action of radiation of high-energy carbon dioxide, neodymium-AIH and holmium lasers. Biul. Ukr. asots. neirokhirurhiv [Bull.of the Ukr. Assoc. of Neurosurgeons]. 1998;5:136-7. (in Russian)

11. Sigal VL, Bidnenko VN. Mechanism of destruction of tumor tissue with local hyperthermia. Vestnik novyih meditsinskih tehnologiy [Herald of new medical technologies]. 2000;4:105-6. (in Russian)

12. Gamache FW, Morgello S. The histopathological effect of the $\mathrm{CO} 2$ versus the KTP laser on the brain and spinal cord: a canine model. Neurosurgery. 1993;32:100-4.

13. Goebel KR. Fundamentals of laser science. Acta Neurochirurgica. 1994;61:20-3.

14. Rossomoff HL, Carroll F. Effect of laser on brain and neoplasm. Surg Forum. 1965;16:431-3. 
15. Stellar S. A study of the effects of laser light on nervous tissue. Proc 3rd Int Congr Neurol Surg. Copenhagen; 1965; p. 542-51.

16. Rahmathuila G, Recinos PF, Kamian K, Mohammadi AM, Ahluwalia MS, Barnett GH. MRI-guided laser interstitial thermal therapy in neuro-oncology: a review of its current clinical applications. Oncology. 2014;87(2):67-82.

17. Eljamel MS, Goodman C, Moseley H. ALA and Photofrin fluorescence-guided resection and repetitive PDT in glioblastoma multiforme: a single centre Phase III randomised controlled trial. Lasers Med Sci. 2008;23(4):361-7.

18. Iancu C, editor. Advances in Endoscopic Surgery. Croatia: InTech; 2011. Chapter 10, Technical and clinical evolution of modern neuroendoscopy; p. 175-90.

19. Hawasli AH, Kim AH, Dunn GP, Tran DD, Leuthardt EC. Stereotactic laser ablation of high-grade gliomas. Neurosurg Focus. 2014 Dec;37(6): E1.
20. Missios S, Bekelis K, Barnett GH. Renaissance of laser interstitial thermal ablation. Neurosurg Focus. 2015;38(3):E13.

21. Stranadko EF. Basic mechanisms of photodynamic therapy (literature review). Fotobiol. ta Fotomed. [Photobiol. and Photomed.]. 1999;1:36-43. (in Russian)

22. Fedulov AS, Sakovich II, Sliakhtsin SV, Trukhachova TV. Photodynamic therapy of 44 high-grade gliomas with Photolon Results of the open-label randomized clinical trial. Photodiagn. Photodyn. Ther. 2008;5:7.

23. Mang TS. Combination studies of hyperthermia induced by the Nd:YAG laser as an adjuvant to photodinamic therapy. Lasers Surg Med. 1990;10(2):173-8.

24. Vanaclocha V, Sureda M, Azinovic I, Rebollo J, Cañón R, Sapena NS, et al. Photodynamic therapy in the treatment of brain tumours. A feasibility study. Photodiagnosis Photodyn Ther. 2015 Sep;12(3):422-7. 